\title{
An Differential Impact analysis of Rural Self Help Groups on Development of Women Farmers in Dharmapuri District
}

\author{
R. Ezhilarasi*, J. S. Amarnath and P. Aishwarya \\ Department of Agricultural Economics, Tamil Nadu Agricultural University, Agricultural \\ College and Research Institute, Madurai, TN, India \\ *Corresponding author
}

\section{Keywords}

Self Help Group, Income, Saving, Economic empowerment, Employment generation, Asset creation, Decision making, Productive efficiency, Income generation rate, Repayment rate, Log it model, CobbDouglas production function

\section{Article Info}

Accepted:

08 December 2020 Available Online: 10January 2021
Women in India are major producers of food in terms of value, volume and number of hours worked. It is observed that women play a significant and crucial role in agricultural development and allied activities. Further the Self-help group's genesis had further kindled the women empowerment in agriculture. In Dharmapuri district of Tamil Nadu, India, the SHGs have a considerable presence and especially contributing to development of women. These SHGs have enhanced the income, employment and asset position of rural women and had increased their decision making activities. Hence to study these impacts, the study was proposed. Percentage analysis, Cobb-Douglas production function and Log it model were the analytical tools used to evaluate the objectives. The results revealed that in both the SHG groups, more proportion of SHG members was in Rs. 5000-Rs. 10000 income groups. A comparative higher saving was observed in NGO SHG and a comparative low saving was observed in Government SHG. After joining SHG, the economic empowerment occurred in both the SHGs. Higher employment days in categories of 100150 days, 150-200 days and above 200 days was observed in NGO SHG even though the mean employment was similar in both the groups. The asset ownership was higher in NGO SHGs as compared to Government SHGS. In both the SHGs, women respondents consulted other family members in economic activities of purchase and sales decision and in household activity, they themselves taken the decision. NGO SHG performed better with respect to productive efficiency, income generation rate and repayment rate than Government SHG. First three major constraints faced by Government SHG women were lack of knowledge of account procedures followed by Improper training facilities and less marketing Opportunities for product. Whereas in NGO SHGs, the major constraints found was are more borrowings followed by inadequate fund and lack of knowledge of account procedures.

\section{Introduction}

Women in India are major producers of food in terms of value, volume and number of hours worked. Nearly 78 per cent of all economically active women are engaged in agriculture as compared to 63 per cent of men. Almost 50 per cent of rural female workers are classified as agricultural labourers and 37 per cent are cultivators. About 70 percent of farm work was performed by women. It is observed that 
women play a significant and crucial role in agricultural development and allied fields including main crop production, live-stock production, horticulture, post-harvesting operations, agro/social forestry and fishing. Further the Self-help group's genesis had further kindled the women empowerment in agriculture.

In Dharmapuri district of Tamil Nadu, India, the SHGs have a considerable presence and especially contributing to development of women. These SHGs have enhanced the income, employment and asset position of rural women and had increased their decision making activities.

The SHGs also performed functionally and improved the provision of credit. Further, the SHGs are involved in the processing and marketing of farm products.

Hence to study these impacts, the study was proposed. Also, Agricultural Technological Modernization Agency (ATMA) SHGs and Non-Governmental Organization SHGs differ in their pursuit of development of women. Hence a comparative analysis of these two broad groups of SHGs was made throughout the study.

The main objectives of this study include to study the income, employment and asset position of rural women across self help groups. To study the decision making in farm activities. To study the performance of self help group and to study the determinants of credit. And also to study the constraints faced by women in availing micro credit.

\section{Materials and Methods}

\section{Sampling design}

Dharmapuri district was purposively selected for the study.Twenty Self Help Groups(SHG) were selected randomly and out of 20 self help groups, ten were Government Self Help Groups and another ten were NonGovernmental Organization Self Help Groups. In each Self Help Group, ten women beneficiaries were selected randomly for data collection. Hence the sample size was 200.

\section{Multiple linear regression analysis}

Multiple linear regression models are used to study the linear relationship between a dependent variable and several independent variables by fitting a linear equation to observed data samples (Coelho-Barros et al., 2008). The generic form of the linear regression model is

$$
\mathrm{Y}=\mathrm{a} \mathrm{X}_{1}{ }^{\mathrm{b} 1} \mathrm{X}_{2}{ }^{\mathrm{b} 2} \mathrm{X}_{3}{ }^{\mathrm{b} 3} \mathrm{X}_{4}{ }^{\mathrm{b} 4} \mathrm{X}_{5}^{\mathrm{b} 5} \mathrm{X}_{6}{ }^{\mathrm{b} 6} \mathrm{X}_{7}{ }^{\mathrm{b} 7} \mu_{\mathrm{t}}
$$

Where $Y$ is the dependent variable, $\mathrm{X}_{1}, \mathrm{X}_{2} \ldots$, $X_{K}$ are the independent or explanatory variables, and $I$ index the $n$ sample observations, the term $\mu_{\mathrm{t}}$ is a random error term.

$\mathrm{X}_{1}=$ Age in years

$\mathrm{X}_{2}=$ Social groups $(\mathrm{sc} / \mathrm{st}=1$, other caste $=0)$

$\mathrm{X}_{3}=$ Education (year of schooling)

$\mathrm{X}_{4}=$ Training $(\mathrm{yes}=1, \mathrm{no}=0)$

$\mathrm{X}_{5}=$ Land holding (ha)

$\mathrm{X}_{6}=$ Family size (numbers)

$\mathrm{X}_{7}=$ Income generating activities $(\mathrm{yes}=1, \mathrm{no}=0)$

\section{Logit model}

In this model, it was assumed that the decisions made by women depended on the variables such as economic and non economic factors. Based on past studies, important variables like age, marital status, women's education and total income have been considered in the present analysis to study their influence on decision making by rural women. Let the qualitative dependent variable (decision making) be described by Y.Y assumes only two values viz., 1 and 0 . 
A simple logit model of the form is given below $Y_{i}=\beta_{1}+\beta_{2} X_{i}+u_{I}$

Where,

$\mathrm{Y}_{\mathrm{I}}=1$, if the women took decision; 0, otherwise

$\mathrm{X}_{\mathrm{i}}=$ economic and non-economic factors

$\grave{\mathrm{u}}_{\mathrm{I}}=$ the disturbance term

It is postulated that probability if taking decision depended on following attributes.

$\mathrm{Z}_{\mathrm{i}}=\beta_{1}+\beta_{2}(\mathrm{MS})+\beta_{3}(\mathrm{INCOME})+\beta_{4}(\mathrm{AGE})+$ $\beta_{5}(\mathrm{MAEDN})+\mathrm{e}$

Where,

$\mathrm{Z}_{\mathrm{I}}=1$, if women taking decision and 0 , otherwise

MS - marital status

INCOME - Gross income of the women

AGE -Age of women in years

MAEDN-Formal education of women head of household in school years

\section{Results and Discussion}

Income, employment, asset position and distribution of income

\section{Annual income of SHG members}

The annual income of SHG members is presented in Table 1. It could be observed from the table that in both the group of SHGs, the highest proportion of members belonged to Rs. 5000- Rs.10000 group of annual income and the said proportion was 40 per cent in Government SHGs and 39 per cent in NGO SHGs. In Government SHGs, the next highest proportion was below Rs. 5000 income with a proportion of 22 per cent and in NGO SHGs, the next highest proportion was above Rs. 20000 income with a proportion of 22 per cent. There was no much discernible difference was noticed between Rs. 10000- Rs.15000 and Rs. 15000Rs.20000 income groups. Thus, it could be concluded from the table that in both the SHG groups, more proportion of SHG members was in Rs. 5000-Rs. 10000 income group.

\section{Annual saving of SHG members}

The annual saving of SHG members is furnished in Table 2. It could be observed from the table that in Government SHG, the low annual saving category of RS. 200-300 was observed with a highest proportion of 66 per cent followed by Rs. 300-500 category with a proportion of 20.00 per cent. The other higher saving categories were marginally present in this SHG. On the other hand, in NGO SHGs, the higher saving categories of Rs. 500-1000 and Rs.1000-1500 were high with a higher proportion of 42 per cent and 34 per cent. The low saving categories of Rs. 200-300 and Rs. 300-500 was observed with a lower proportion of ten each. Thus it could be concluded from the table that a comparative higher saving was observed in NGO SHG and a comparative low saving was observed in Government SHG.

\section{Economic improvement of women}

The economic improvement of women through self help groups with comparative analysis of before and after situation is presented in Table 3. It could be seen from the table that after joining the SHG, the income and saving increased in both the SHG categories even though the expenses did not show much difference. The income increase was 26.67 per cent in Government SHG and in NGO SHG; the increase was higher with a proportion of 36.73 per cent. The savings increase was 60.00 per cent in Government 
SHG and in NGO SHG, the increase was higher with a proportion of 81.82 per cent. With savings, the purchase of durable goods and livestock was undertaken, with a higher proportion in NGO SHG as compared to Government SHG. The possession of durable goods in NGO SHG was higher by 25.00 per cent over Government SHG while, in possession of livestock, much increase of 27.00 per cent was observed in NGO SHG over Government SHG. Thus, it could be concluded from the table that after joining SHG, the economic empowerment occurred in both the SHGs and higher empowerment was observed in NGO SHG.

\section{Employment Days per annum of SHG Members}

The employment days per annum of SHG Members is presented in Table 4. It could be observed from the table that distribution of employment showed difference between SHG groups even though the mean days of employment was similar with 678 in Government SHG and 683 in NGO SHG. Even though the below 50 man days employment was highest in both the SHG groups, the proportion was much higher in in Government SHG with a proportion of 64 per cent and it was only with a proportion of 37 per cent in NGO SHG. The next higher employment category in Government SHG was 50-100 with a proportion of 23 per cent. The other higher employment categories were marginally present in this SHG group. In NGO SHG, the second highest proportion was observed for 100-150 employment group with a proportion of 24 per cent followed by 50100 employment days group with a proportion of 19 per cent. The other higher employment categories were also significantly present with a proportion of 11 per cent in 150-200 employment group and 9 per cent in above 200 employment day group. Thus, it could be concluded from the table that higher employment days in categories of 100-150 days, 150-200 days and above 200 days was observed in NGO SHG even though the mean employment was similar in both the groups.

\section{Asset ownership of sample respondents}

The details of asset ownership of sample respondents are presented in Table 5. It could be seen from the table that with regard to type of house, tiled house was more prevalent in both NGO SHGs and in Government SHGs with a proportion of 73 per cent and 78 per cent respectively. Next, concrete house was more prevalent with a proportion of 24 per cent and 15 per cent in NGO SHGs and in Government SHGs respectively. Thatched houses occupied lower proportion in both the SHGs. Material assets were more prevalent in NGO SHGs with a proportion of 47 per cent as compared to Government SHGs with a proportion of 36 per cent. The LPG gas connection was also high in NGO SHGs with a proportion of 85.00 per cent as compared to Government SHGs with a proportion of 70.00 per cent. Thus this analysis showed that asset ownership was higher in NGO SHGs as compared to Government SHGS.

\section{Decision making role of respondent women}

The decision making role of respondent women is presented in Table 6 . It could be seen from the table that in case of economic activities, both in purchase and sales decision, the more proportion of purchase decision and sales decision was taken in consultation with other family members followed by more proportion of initiation of decisions and lastly with actual decision taken. The same situation was prevailed in both Government SHGs and NGO SHGs. In Government SHG, in purchase decisions, the proportion of decision taken in consultation with other family members was 86.60 per cent for purchase of 
land, 76.40 per cent for purchase of cattle, 65.30 per cent for purchase of inputs and 92.30 per cent for purchase of machinery and equipments.

Similar proportion was observed for NGO SHGs with 89.50 per cent for purchase of land, 79.30 per cent for purchase of cattle and 69.30 per cent for purchase of inputs. In sales decision also, the decision taken in consultation with other family members was high with proportions of 92.30 per cent in sale of land, 86.60 per cent in sale of cattle and 89.50 per cent in sale of products in Government SHGs. In NGO SHGs, similar proportion was observed with 95.40 per cent in sale of land, 89.60 per cent in sale of cattle and 93.10 per cent in sale of products. In employment of labour, sending family members for work and in borrowings also the decision taken in consultation with other family members was high for both Government SHGs and NGO SHGs.

With regard to household activity, different situation was prevailed in both Government SHGs and NGO SHGs with actual decision was taking the preponderance followed by consultation with other family members and lastly with initiation of decisions. In Government SHG, the proportion of actual decision taken was high with 76.40 per cent for purchase or sale of durable assets, 80.30 per cent for purchase of provisions, 90.30 per cent for purchase of clothes, 76.30 per cent for menu for cooking and 50.30 per cent for education of children. In NGO SHG, the proportion of actual decision taken was also high with 80.10 per cent for purchase or sale of durable assets, 84.30 per cent for purchase of provisions, 93.50 per cent for purchase of clothes, 79.20 per cent for menu for cooking and 54.80 per cent for education of children. Thus it could be concluded from the table that in both the SHGs, women respondents consulted other family members in economic activities of purchase and sales decision and in household activity, they themselves taken the decision.

Table.1 Annual Income of SHG Members

\begin{tabular}{|c|l|c|c|c|c|}
\hline SI.No. & Annual income(Rs.) & GovtSHGs & Mean income & NGO SHGs & Mean income \\
\hline $\mathbf{1}$ & Below 5000 & $\begin{array}{c}22 \\
(22.00)\end{array}$ & 4678 & $\begin{array}{c}11 \\
(11.00)\end{array}$ & 3970 \\
\hline $\mathbf{2}$ & $5000-10000$ & $\begin{array}{c}40 \\
(40.00)\end{array}$ & 8479 & $\begin{array}{c}39 \\
(39.00)\end{array}$ & 8650 \\
\hline $\mathbf{3}$ & $10000-15000$ & $\begin{array}{c}15 \\
(15.00)\end{array}$ & 14762 & $\begin{array}{c}13 \\
(13.00)\end{array}$ & 14398 \\
\hline $\mathbf{4}$ & $15000-20000$ & $\begin{array}{c}8 \\
(8.00)\end{array}$ & 18594 & $\begin{array}{c}15 \\
(14.00)\end{array}$ & 19782 \\
\hline $\mathbf{5}$ & Above 20000 & $\begin{array}{c}15 \\
(15.00)\end{array}$ & 24823 & $\begin{array}{c}22 \\
(22.00)\end{array}$ & 26465 \\
\hline & Total & $\begin{array}{c}100 \\
(100.00)\end{array}$ & $\mathbf{7 1 , 3 3 6}$ & $\begin{array}{c}100 \\
(100.00)\end{array}$ & $\mathbf{7 3 , 2 6 5}$ \\
\hline
\end{tabular}

Figures in parentheses indicate the percentage to total 
Table.2 Annual saving of SHG Members

\begin{tabular}{|c|l|c|c|}
\hline Sl.No. & Annual saving(Rs.) & Government SHGs & NGO SHGs \\
\hline $\mathbf{1}$ & Nil & 0 & 0 \\
& & $(0.00)$ & $(0.00)$ \\
\hline $\mathbf{2}$ & $200-300$ & 66 & 10 \\
& & $(66.00)$ & $(10.00)$ \\
\hline $\mathbf{3}$ & $300-500$ & 20 & 10 \\
& & $(20.00)$ & $(10.00)$ \\
\hline $\mathbf{4}$ & $500-1000$ & 11 & 42 \\
& & $(11.00)$ & $(42.00)$ \\
\hline $\mathbf{5}$ & $1000-1500$ & 3 & 34 \\
& & $(3.00)$ & $(34.00)$ \\
\hline $\mathbf{6}$ & Above 1500 & 0 & 4 \\
& & $(0.00)$ & $(4.00)$ \\
\hline & Total & $\mathbf{1 0 0 . 0 0}$ & $\mathbf{1 0 0 . 0 0}$ \\
\hline
\end{tabular}

Figures in parentheses indicate the percentage to total

Table.3 Economic improvement of women through self help groups (in Rupees)

\begin{tabular}{|c|l|c|c|c|c|}
\hline Sl. No. & \multicolumn{1}{|c|}{ Particulars } & $\begin{array}{c}\text { Before joining } \\
\text { Govt SHG }\end{array}$ & $\begin{array}{c}\text { After joining } \\
\text { Govt SHG }\end{array}$ & $\begin{array}{c}\text { Before joining } \\
\text { NGO SHG }\end{array}$ & $\begin{array}{c}\text { Afterjoining } \\
\text { NGO SHG }\end{array}$ \\
\hline $\mathbf{1}$ & Annualincome & 7500 & 9500 & 7745 & 10590 \\
\hline $\mathbf{2}$ & Annual expenses & 6000 & 7100 & 4445 & 4590 \\
\hline $\mathbf{3}$ & Annual Savings & 1500 & 2400 & 3300 & 6000 \\
\hline $\mathbf{4}$ & $\begin{array}{l}\text { Possessionof } \\
\text { durable goods }\end{array}$ & 700 & 1200 & 1300 & 1500 \\
\hline $\mathbf{5}$ & $\begin{array}{l}\text { Possession of } \\
\text { livestock }\end{array}$ & 800 & 1200 & 2000 & 4500 \\
\hline
\end{tabular}

Table.4 Employment Days per annum of SHG Members

\begin{tabular}{|c|c|c|c|c|c|}
\hline Sl.No. & Employment days & Government SHGs & Mean days & NGO SHGs & Mean days \\
\hline 1 & Below 50 & $\begin{array}{c}64 \\
(64.00)\end{array}$ & 48 & $\begin{array}{c}37 \\
(37.00)\end{array}$ & 39 \\
\hline 2 & $50-100$ & $\begin{array}{c}23 \\
(23.00)\end{array}$ & 85 & $\begin{array}{c}19 \\
(19.00)\end{array}$ & 84 \\
\hline 3 & $100-150$ & $\begin{array}{c}6 \\
(6.00)\end{array}$ & 145 & $\begin{array}{c}24 \\
(24.00)\end{array}$ & 147 \\
\hline 4 & $150-200$ & $\begin{array}{c}2 \\
(2.00)\end{array}$ & 180 & $\begin{array}{c}11 \\
(11.00)\end{array}$ & 189 \\
\hline \multirow[t]{2}{*}{5} & Above 200 & $\begin{array}{c}5 \\
(5.00)\end{array}$ & 220 & $\begin{array}{c}9 \\
(9.00)\end{array}$ & 224 \\
\hline & Total & $\begin{array}{c}100 \\
(100.00)\end{array}$ & 678 & $\begin{array}{c}100 \\
(100.00)\end{array}$ & 683 \\
\hline
\end{tabular}

Figures in parentheses indicate the percentage to total 
Table.5 Asset ownership of sample respondents

\begin{tabular}{|r|l|c|c|}
\hline Sl.No. & \multicolumn{1}{|c|}{ Particulars } & Government SHGs & NGO SHGs \\
\hline $\mathbf{1}$ & Type of house & & \\
\hline & a)Thatched & 7.00 & 3.00 \\
\hline & b)Tiled & 78.00 & 73.00 \\
\hline & c)Concrete & 15.00 & 24.00 \\
\hline $\mathbf{2}$ & Material assets* & 36.00 & 47.00 \\
\hline $\mathbf{3}$ & LPG gas connection (\%) & 70.00 & 85.00 \\
\hline
\end{tabular}

Figures in parentheses indicate the percentage to total

*Material assets included television set, mixie, grinder, steel items and gold ornaments

Table.6 Decision making role of respondent women

\begin{tabular}{|c|c|c|c|c|c|c|c|}
\hline \multirow[t]{2}{*}{ Sl. .No. } & \multirow{2}{*}{$\begin{array}{c}\text { Decision } \\
\text { making }\end{array}$} & \multicolumn{3}{|c|}{ Government SHGs } & \multicolumn{3}{|c|}{ NGO SHGs } \\
\hline & & $\begin{array}{c}\text { Initiation of } \\
\text { decisions } \\
(\%)\end{array}$ & $\begin{array}{c}\text { Consultation with } \\
\text { other family } \\
\text { members } \\
(\%)\end{array}$ & $\begin{array}{c}\text { Decision } \\
\text { taken } \\
(\%)\end{array}$ & $\begin{array}{c}\text { Initiation of } \\
\text { decisions } \\
(\%)\end{array}$ & $\begin{array}{c}\text { Consultation with } \\
\text { other family } \\
\text { members } \\
(\%)\end{array}$ & $\begin{array}{c}\text { Decision } \\
\text { taken } \\
(\%)\end{array}$ \\
\hline 1 & $\begin{array}{l}\text { Economic } \\
\text { activities }\end{array}$ & & & & & & \\
\hline (a) & $\begin{array}{l}\text { Purchase } \\
\text { decisions }\end{array}$ & & & & & & \\
\hline 1 & Purchase of land & 10.90 & 86.60 & 6.30 & 12.30 & 89.50 & 7.90 \\
\hline 2 & $\begin{array}{l}\text { Purchase of } \\
\text { cattle }\end{array}$ & 20.80 & 76.40 & 7.20 & 22.70 & 79.30 & 9.30 \\
\hline 3 & $\begin{array}{l}\text { Purchase of } \\
\text { inputs }\end{array}$ & 17.70 & 65.30 & 8.20 & 20.90 & 69.30 & 9.20 \\
\hline 4 & $\begin{array}{l}\text { Purchase of } \\
\text { machinery and } \\
\text { equipments }\end{array}$ & 8.80 & 93.20 & 4.70 & - & - & - \\
\hline (b) & Sale decision & & & & & & \\
\hline 1 & Sale of land & 11.90 & 92.30 & 6.40 & 13.40 & 95.40 & 8.40 \\
\hline 2 & Sale of cattle & 15.90 & 86.60 & 5.70 & 17.60 & 89.60 & 7.30 \\
\hline 3 & Sale of products & 20.40 & 89.50 & 7.90 & 22.90 & 93.10 & 9.40 \\
\hline (c) & $\begin{array}{l}\text { Employment of } \\
\text { labour }\end{array}$ & 80.40 & 93.76 & 3.40 & 82.60 & 94.70 & 6.40 \\
\hline (d) & $\begin{array}{l}\text { Sending family } \\
\text { members for } \\
\text { work }\end{array}$ & 45.30 & 96.40 & 5.70 & 47.80 & 98.30 & 5.70 \\
\hline (e) & Borrowings & 35.90 & 98.20 & 5.30 & 40.80 & 99.30 & 7.90 \\
\hline 2 & $\begin{array}{l}\text { Household } \\
\text { activity }\end{array}$ & & & & & & \\
\hline 1 & $\begin{array}{l}\text { Purchase or sale } \\
\text { of durable assets }\end{array}$ & 34.00 & 76.40 & 76.40 & 37.20 & 79.30 & 80.10 \\
\hline 2 & $\begin{array}{l}\text { Purchase of } \\
\text { provisions }\end{array}$ & 58.00 & 65.30 & 80.30 & 62.10 & 68.40 & 84.30 \\
\hline 3 & $\begin{array}{l}\text { Purchase of } \\
\text { clothes }\end{array}$ & 54.00 & 83.20 & 90.30 & 57.10 & 90.30 & 93.50 \\
\hline 4 & $\begin{array}{l}\text { Menu for } \\
\text { cooking }\end{array}$ & 93.00 & 70.40 & 76.30 & 97.10 & 3.00 & 79.20 \\
\hline 5 & $\begin{array}{l}\text { Education of } \\
\text { children }\end{array}$ & 15.00 & 45.30 & 50.30 & 18.40 & - & 54.80 \\
\hline
\end{tabular}


Table.7 Decision making of women in Self Help Groups

\begin{tabular}{|r|l|c|c|c|c|}
\hline \multirow{2}{*}{ Sl. No. } & \multicolumn{1}{|c|}{ Particulars } & \multicolumn{2}{c|}{ Government SHG } & \multicolumn{2}{c|}{ NGO SHG } \\
\cline { 3 - 6 } & & Coefficient & Odd Ratio & Coefficient & Odd Ratio \\
\hline $\mathbf{1}$ & Constant & 1.60 & 0.00 & 2.10 & 0.00 \\
\hline $\mathbf{2}$ & Marital status & $0.52^{* *}$ & 1.68 & $0.07^{* *}$ & 1.07 \\
\hline $\mathbf{3}$ & Caste & $0.20^{*}$ & 1.22 & $0.004^{* *}$ & 1.00 \\
\hline $\mathbf{4}$ & Age & $0.51^{*}$ & 1.66 & $0.24^{*}$ & 1.27 \\
\hline $\mathbf{5}$ & Education & $0.09^{* *}$ & 1.09 & $0.04^{* *}$ & 1.04 \\
\hline $\mathbf{6}$ & Income & $0.14^{* *}$ & 1.15 & $0.76^{*}$ & 2.13 \\
\hline
\end{tabular}

** Significance at 1 per cent level *significance at 5 per cent level

Table.8 Productive Efficiency of SHG Credit

\begin{tabular}{|c|l|c|c|}
\hline SI.No. & \multicolumn{1}{|c|}{ Particulars } & Government SHG & NGO SHGs \\
\hline A. & Productive Efficiency: & & \\
\hline & a) Capital-output ratio (Rs.) & 21.53 & 24.98 \\
\hline & $\begin{array}{l}\text { b) Annual rate of return or productivity of } \\
\text { credit (\%) }\end{array}$ & 7.58 & 10.65 \\
\hline B. & $\begin{array}{l}\text { Income per Annum (Rs.): } \\
\text { a) Income generation }\end{array}$ & 24000 & 34140 \\
\hline & b) Pre-SHG credit family income & 90000 & 92940 \\
\hline & c) Post-SHG credit family income & 114000 & 127080 \\
\hline & d) Income Generation rate (\%) & 65.05 & 73.56 \\
\hline & e) Poverty alleviation rate (\%) & 29.46 & 37.67 \\
\hline C. & Savings and Repayment: & & 500 \\
\hline & a) Average savings per month (Rs.) & 200 & 32.29 \\
\hline & b) Repayment rate (\%) & 28.19 & \\
\hline
\end{tabular}

Table.9 Determinants of credit of SHG

\begin{tabular}{|c|l|c|c|}
\hline \multirow{2}{*}{ Sl. No. } & \multicolumn{1}{|c|}{ Particular } & \multicolumn{2}{c|}{ Regression Coefficient } \\
\cline { 3 - 4 } & & Government NGO & NGO SHG \\
\hline $\mathbf{1 .}$ & Constant & 0.169 & 0.37 \\
\hline $\mathbf{2 .}$ & Age (years) & 0.004 & 0.09 \\
\hline $\mathbf{3 .}$ & $\begin{array}{l}\text { Social groups } \\
\text { (SC/ST =1, others caste =0) }\end{array}$ & 0.06 \\
\hline $\mathbf{4 .}$ & Education (Years of schooling) & $0.12^{*}$ & $0.28^{*}$ \\
\hline $\mathbf{5 .}$ & $\begin{array}{l}\text { Training } \\
\text { (Yes =1,No =0) }\end{array}$ & $0.47^{* *}$ & $0.44^{*}$ \\
\hline $\mathbf{6 .}$ & Land holding (ha) & $0.02^{*}$ & $0.47^{*}$ \\
\hline $\mathbf{7 .}$ & Family size (Number) & 0.03 & 0.07 \\
\hline $\mathbf{8 .}$ & $\begin{array}{l}\text { Income generating activities } \\
\text { (Yes =1, No=0) }\end{array}$ & $0.49^{*}$ & $0.41^{* *}$ \\
\hline & \multicolumn{1}{|c|}{ Adjusted R Square } & 0.75 & 0.75 \\
\hline
\end{tabular}

$* *=$ significance level at 1 per cent $*=$ significance level at 5 per cent 
Table.10 The constraints faced by SHG women in availing micro credit

\begin{tabular}{|c|l|c|c|c|c|}
\hline SI. No. & \multicolumn{1}{|c|}{ Problems } & \multicolumn{2}{|c|}{ Govt SHGs } & \multicolumn{2}{c|}{ NGO SHGs } \\
\cline { 3 - 6 } & & \multicolumn{1}{|c|}{ Mean score } & Rank & Mean score & Rank \\
\hline $\mathbf{1}$ & Lack of Knowledge of Account procedures & 60.60 & I & 55.60 & III \\
\hline $\mathbf{2}$ & $\begin{array}{l}\text { Improper Training } \\
\text { Facilities }\end{array}$ & 55.43 & II & 51.63 & V \\
\hline $\mathbf{3}$ & Less marketing opportunities for product & 53.23 & III & 52.89 & IV \\
\hline $\mathbf{4}$ & Migration for employment & 49.96 & IV & 45.67 & VI \\
\hline $\mathbf{5}$ & Unhealthy Competition & 45.53 & V & 42.89 & VII \\
\hline $\mathbf{6}$ & Banks having different view towardsSHG & 41.43 & VI & 28.90 & VIII \\
\hline $\mathbf{7}$ & $\begin{array}{l}\text { Lack of coordination and cooperation } \\
\text { between members }\end{array}$ & 28.46 & VII & 23.63 & IX \\
\hline $\mathbf{8}$ & More borrowings & 28.23 & VI & 61.73 & I \\
\hline $\mathbf{9}$ & Inadequate fund & 24.13 & IX & 59.60 & II \\
\hline $\mathbf{1 0}$ & Lack of entrepreneurial qualities & 18.96 & X & 17.86 & X \\
\hline
\end{tabular}

\section{Decision making - Logit model}

\section{Decision making of women in government self help groups}

Decision making of women NGO SHG is presented in Table 7 . It could be seen from the table that decision making of women were significantly influenced by marital status, caste; age, education, and income. The coefficient of marital status, education and income were positive and significant at one per cent level. The coefficient of caste and age were positive and significant at five per cent level. Marital status with odd ratio of 1.68 (greater than one), indicated that married women were 1.68 times more likely to take decision as compared to single or divorced women. The computed odd ratio of education was 1.09 (greater than one) which implied that the farmers with education were 1.09 times more likely to influence the decision making of women as compared to illiterate women. The coefficient for income was significant and its odd ratio of 1.15 (greater than one) which implied that earning women were more likely to influence the decision making than non earning women. The odds ratio of caste was 1.22 which indicated that backward community groups were more vocal in decision making than scheduled caste. The odds ratio of 1.66 for age indicated that old people were 1.66 times more likely to influence the decision making of women.

\section{Decision making of women in NGOs Self Help Groups}

Decision making of women in NGO SHG is presented in Table 7 . It could be seen from the table that decision making of women were significantly influenced by marital status, caste, age, education, and income. The coefficient of marital status, caste and education were positive and significant at one per cent level. The coefficient of age and income were positive and significant at five per cent level. Marital status with odd ratio of 1.07 (greater than one), indicated that married women were 1.07 times more likely to take decision as compared to single or divorced women. The computed odd ratio of education was 1.04(greater than one) which implied that the farmers with education were 1.04 times more likely to influence the decision making of women as compared to illiterate women. The coefficient for income was also significant and its odd ratio was 2.13(greater 
than one) which implied that earning women more likely to influence the decision making than non earning women. The odds ratio of caste 1.00 indicated that both scheduled caste and backward community groups are equal in decision making. The odds ratio of 1.27 for age indicated that old people were 1.27 times more likely to influence the decision making of women. Banerjee et al., (2008) studied the adoption technology using binary logit model and result showed that adoption was more likely to those who had already adopted precision farming practices and had used computers for farm management, farmers with larger farm and younger and more affluent farmers were significantly influencing the adoption of GPS guidance system by cotton producers. Ololade and Olagunju (2013) estimated the determinants of access to credit among the rural farmers using logit model technique and the result revealed that sex, marital status, lack of guarantor, high interest rate and access to credit were found significant related to the determinants of access to credit among rural farmer in Oyo state, Nigeria. Jaza et al., (2018) also worked in logit model and the result indicated that farmer's age, gender, farming experience, practice of other livestock activities, frequency of contact with Extension agents, access to credit for financing activities and the farm income favoured the Goat raising activity by farmers.

\section{Performance of shg and determinants of credit}

\section{Productive efficiency, income generation rate and repayment rate of SHG credit}

The productive efficiency, income generation rate and repayment rate of $\mathrm{SHG}$ credit is presented in Table 8 . It could be seen from the table that that both the SHGs performed well with regard to capital-output ratio, productivity of credit, income generation rate, poverty alleviation rate and repayment rate and among which, NGO SHG performed superior. The capital-output ratio, productivity of credit, income generation rate, poverty alleviation rate and repayment rate was higher in NGO SHG with 24.98 per cent, 10.65 per cent, 73.56 per cent, 37.67 per cent and 32.29 per cent. The same was lower in Government SHG with 21.53 per cent, 7.58 per cent, 65.05 per cent, 29.46 per cent and 28.19 per cent. Thus it could be concluded from the table that on comparative analysis, NGO SHG performed better with respect to productive efficiency, income generation rate and repayment rate than Government SHG.

\section{Determinants of credit}

\section{Government SHG}

The estimated Cobb-Douglas production function for determinants of credit of Government SHGs is furnished in the table 9.It could be seen from the table 9 that the adjusted coefficient of multiple determinations of $\overline{R^{2}}$ was 0.75 revealing that the production function model was a good fit and indicated that 75.00 per cent of variation in determinants of credit was influenced by the explanatory variables included in the model. The credit level in Government SHGs responded significantly to the variables of education (years of schooling), training, land holding and income generating activities. The coefficients of education, training and land holding were positive and significant at five per cent level with the coefficient values of $0.12, \quad 0.02$ and 0.49 respectively. The coefficient of training was positive and significant at one per cent level with the coefficient value of 0.47 . These positive coefficient values indicated that an increase in the level of education, training, land holding and income generating activities by one per cent from the existing mean level, ceteris paribus, would increase the credit level of 
Government SHGs by $0.12,0.47,0.02$ and 0.49 per cent respectively.

\section{NGO self help group}

Cobb-Douglas production function was used to estimate the output elasticity with respect to key inputs. The estimated Cobb-Douglas productions function for determinants of credit of NGO self help group presented in the table 9.It could observed that the adjusted coefficient of multiple determinations of $\overline{R^{2}}$ was 0.75 indicating that 75.00 per cent of total variation in credit level of NGO SHGs member was influenced by the explanatory variables included in the model. The credit level of NGO SHGs responded significantly to the variables of education (years of schooling), training, land holding and income generating activities. The coefficients of education, training and land holding were positive and significant at five per cent level with the coefficient values of $0.28,0.44$, and 0.48 respectively. The coefficient of income generating activities are positive and significant at one per cent level with the coefficient value of 0.41 .These coefficient positive values indicated that an increase in the variable level of education, training, land holding and income generating activities by one per cent from the existing mean level, ceteris paribus, would increase the credit level of NGO SHGs by $0.28,0.44,0.48$, and 0.41 per cent respectively.

Nagaraj et al., (2009) reported the similar result that Education, Training and Income Generating activities (IGA) were positive and significantly influencing the economic performance of selfhelp groups. Durgarani and Gokilavani (2015)study also showed that there is a significant association between age, educational qualification, religion, community, and employment status, number of dependents, monthly income, and monthly expenditure on economic empowerment through the multiple regression analysis. Rathiranee and Semasinghe (2015) also used multiple regression analysis in this study and the result revealed that decision making, freedom to mobility and family support were positively associated with women empowerment.

\section{The constraints faced by SHG women}

The constraints faced by SHGs women are presented in Table 10. It could be seen from the table that first three major constraints faced by Government SHG women were lack of knowledge of account procedures with a mean score of 60.60 followed by Improper training facilities with a mean score of 55.43 and less marketing Opportunities for Product with a mean score of 55.23. Whereas in NGO SHGs the major constraints found was are more borrowings with a mean score of 61.73 followed by inadequate fund with a mean score of 59.60 and lack of knowledge of account procedures with a mean score of 55.60. Minor constraints were migration for employment, unhealthy Competition, banks having different view towards SHG, lack of coordination and cooperation between members and lack of entrepreneurial qualities.

In conclusions both the SHGs, the income, savings, economic empowerment, employment generation, asset creation of women respondents had increased and on comparative analysis, NGO SHG performed better than Govt. SHG. Further, in lending credit also, the NGO SHG itself showed better performance in capital-output ratio, productivity of credit, income generation rate, poverty alleviation rate and repayment rate. Hence the State Government should bestow more attention in improved functioning of Govt. SHG. In both the SHGs, women respondents consulted other family members in economic activities of purchase and sales decision and in household activity, they 
themselves taken the decision. Hence proper trainings should be conducted by the Department of women and Social welfare to motivate the women members to take decision in economic activities of purchase and sales decision.

\section{References}

Banerjee, S. B., Martin, S. W., Roberts, R. K., Larkin, S. L., Larson, J. A., Paxton, K. W., ... \& Reeves, J. M. (2008). A binary logit estimation of factors affecting adoption of GPS guidance systems by cotton producers. Journal of agricultural and applied economics, 40 (1379-2016-112703), 345-355.

Nagaraj, N., Chandrakanth, M. G., Acker, D., Chengappa, P. G., Shruthi, H. R., Yadava, C. G., \&Kanwar, R. (2009). Economic performance of self help groups in Karnataka with special reference to Venkatenahalli in South India. Indian Journal of Agricultural Economics, 64 (902-2016-67904).

Ololade, R. A., \&Olagunju, F. I. (2013).
Determinants of access to credit among rural farmers in Oyo State, Nigeria. Global Journal of Science Frontier Research Agriculture and Veterinary Sciences, 13(2), 16-22.

Durgarani, M., \&Gokilavani, R. (2015). Economic empowerment of women through self-help groups: a study in Coimbatore district. International Journal of Economic Research, 12(2).

Rathiranee, Y., \&Semasinghe, D. M. (2015). Factors determining the women empowerment through microfinance: An empirical study in Sri Lanka. International Journal of Social, Behavioural, Educational, Economic, Business and Industrial Engineering, 9(5), 2328-2185.

Jaza, F. A. J., Tsafack, P. P., \&Kamajou, F. (2018).Logit Model of Analysing the Factors Affecting the Adoption of Goat Raising Activity by Farmers in the Nonpastoral Centre Region of Tropicultura, 36(1), 54-62.

\section{How to cite this article:}

Ezhilarasi, R., J. S. Amarnath and Aishwarya, P. 2021. An Differential Impact analysis of Rural Self Help Groups on Development of Women Farmers in Dharmapuri District. Int.J.Curr.Microbiol.App.Sci. 10(01): 601-612. doi: https://doi.org/10.20546/ijcmas.2021.1001.073 